\title{
Grazing and viral lysis vary for different components of the microbial community across an estuarine gradient
}

\author{
Alice C. Ortmann ${ }^{1,2, *}$, R. Courtney Metzger ${ }^{1,2}$, Justin D. Liefer ${ }^{1,2}$, Lucie Novoveska ${ }^{1,2}$ \\ ${ }^{1}$ Department of Marine Sciences, University of South Alabama, Mobile, Alabama 36688, USA \\ ${ }^{2}$ Dauphin Island Sea Lab, Dauphin Island, Alabama 36528, USA
}

\begin{abstract}
The balance between grazing and viral lysis of both photosynthetic and heterotrophic microbes determines the food resources that are available, and how much of each resource is present, for higher trophic levels. Mobile Bay is the fourth largest estuary in the USA, based on river discharge, and is home to a variety of nursery habitats for larvae and juveniles of economically important species which depend for their food on production of organisms of microbial size. To characterize the patterns of growth and removal rates of this fraction of organisms in Mobile Bay, we carried out modified dilution experiments in summer and winter at 3 stations along a salinity and nutrient gradient. Rates of growth, grazing and viral lysis for prokaryotes and dominant phytoplankton (cyanobacteria, diatoms and dinoflagellates) were determined for each experiment. Grazing and viral lysis of prokaryotes did not appear to be related to season or location, and both processes were detected within the bay as well as on the shelf. For phytoplankton, grazing was the dominant removal process inshore in the summer, while viral lysis of phytoplankton was detected in the fall and in winter. In winter, an apparent increase in dinoflagellates, and in the overall biomass of phytoplankton, was concurrent with increased viral lysis, suggesting that recycling by viruses may be an important source of nutrients in coastal waters.
\end{abstract}

KEY WORDS: Grazing · Viral-mediated mortality · Phytoplankton · Prokaryotes · Estuarine · Microbial food web

Resale or republication not permitted without written consent of the publisher

\section{INTRODUCTION}

Estuaries are highly productive systems, and they represent a gradient of conditions from inshore to the offshore coastal regions. Many estuaries are important nursery areas for larvae and juveniles of economically important species of fish. Most of these larvae and juveniles feed on the mesozooplankton, which may graze on eukaryotic phytoplankton (Rollwagen Bollens \& Penry 2003) — but which may also consume heterotrophic protists (Fukami et al. 1999, Nagano \& Decamp 2004, de Figueiredo et al. 2005, Pepin \& Dower 2007). These heterotrophic protists, the microzooplankton, may consume smaller protists (the nano- and pico-zooplankton) or graze directly on heterotrophic or autotrophic prokaryotes. The food available to larval and juvenile fish depends on the rates of growth of the phytoplankton and prokaryotes as well as on the rates of protist grazing and viral lysis. Protist grazing, especially on small phytoplankton and prokaryotes, can create a trophic link between small cells and larval fish, increasing the available food. Viral lysis, however, shunts the biomass into the pool of dissolved organic matter (DOM), reducing the amount of food available for higher trophic levels (Fuhrman 1999, Wilhelm \& Suttle 1999, Suttle 2007). Grazing has been measured by a serial dilution approach (Landry \& Hassett 1982, 
Landry et al. 1995) for several years in a range of environments. In many instances, growth and grazing appear to be nearly balanced (Juhl \& Murrell 2005, Palomares-García et al. 2006, Putland \& Iverson 2007, Paterson et al. 2008), suggesting a strong top-down control of phytoplankton abundance. Viral lysis has been measured in fewer systems, but in many studies, lysis also appears to be a factor controlling the abundance of prokaryotes (Wilhelm et al. 2002, Boras et al. 2009, Karuza et al. 2010) and, in a few instances, phytoplankton (Baudoux et al. 2006, 2008). There are fewer studies in which both grazing and viral lysis have been measured, but often grazing appears to be the dominant process in controlling host abundances (Guixa-Boixereu et al. 1999, PedrósAlió et al. 2000, Evans et al. 2003, Kimmance et al. 2007, Baudoux et al. 2008). It has been suggested that, as grazing is less specific and occurs at higher rates, grazing controls the abundance of prey while viral lysis - being a species- or strain-specific interaction-controls community diversity (Weinbauer 2004, Longnecker et al. 2010).

When both grazing and viral lysis have been estimated, it is often observed that grazing increases both host productivity and viral lysis, with the grazers and viruses acting synergistically and producing results that are not purely additive (Miki \& Yamamura 2005, Weinbauer et al. 2007, Zhang et al. 2007, Bonilla-Findji et al. 2009, Ory et al. 2010). In other cases, antagonistic interactions between grazers and viruses have been documented (Weinbauer et al. 2007, Ory et al. 2010); in these cases, one predator decreases the effects of the other. The interaction between grazers and viruses is further complicated by the fact that the viruses of microzooplankton can lyse grazers (Garza \& Suttle 1995), while grazers can consume viruses (Gonzalez \& Suttle 1993, Miki \& Jacquet 2008). Although many studies have documented strong relationships between biomass, growth and grazing (Juhl \& Murrell 2005, PalomaresGarcía et al. 2006, Putland \& Iverson 2007, York et al. 2010), other studies have indicated an uncoupling of these variables (Lehrter et al. 1999, First et al. 2007, Williams et al. 2008, Ory et al. 2010, Landry et al. 2011). Grazing and/or viral lysis can exhibit patterns different from those of growth, over time or across space, resulting in an uncoupling of the processes.

The majority of studies that have estimated grazing and viral lysis have used chlorophyll a (chl a) as a proxy for phytoplankton biomass. A few studies have used flow cytometry to look at separate phytoplankton groups based on fluorescence and cell complexity (Baudoux et al. 2008, Chen \& Liu 2010). A few other studies have used specific pigments to estimate changes in functional groups of phytoplankton (Strom \& Welschmeyer 1991, Waterhouse \& Welschmeyer 1995, Palomares-García et al. 2006). When analysis of separate groups was carried out, it was found that the different groups of phytoplankton experienced different rates of growth, grazing and lysis.

The Mobile Bay estuary is the fourth largest estuary in the USA, based on discharge (Schroeder \& Wiseman 1999). The estuary is shallow, averaging 2 to $3 \mathrm{~m}$ in depth, with the exception of a narrow shipping channel $\sim 15 \mathrm{~m}$ deep dredged along the western side of the bay. The estuary is dominated by the input of water from the Mobile River, which combines the flow from the Tombigbee and Alabama Rivers, with a mean discharge of $1848 \mathrm{~m}^{3} \mathrm{~s}^{-1}$ (Schroeder \& Wiseman 1999). The main pass into the northern Gulf of Mexico deepens to approximately $10 \mathrm{~m}$, and $85 \%$ of the total discharge empties through this pass. When discharge is high, Mobile Bay can be almost completely fresh water, but low discharge can result in saline waters reaching more than half way up the bay. Although shallow, Mobile Bay often stratifies during the summer months owing to a combination of winds and tides (Park et al. 2007). Combined with diel patterns in photosynthesis, stratification can result in hypoxic to anoxic conditions in the eastern sections of Mobile Bay.

Variability in river discharge, along with salinity and nutrient supply, results in high variability in the biomass and productivity in Mobile Bay. Heterotrophic prokaryote production, $1.2 \mathrm{gC} \mathrm{m}^{2} \mathrm{~d}^{-1}$, exceeds estimates of primary production of 0 to $3.5 \mathrm{gC} \mathrm{m}^{2} \mathrm{~d}^{-1}$ (McManus et al. 2004). In the same study, temperature had the strongest control on prokaryote production, but primary production was variable, and did not appear to have a strong seasonal signal. The relatively low abundances of prokaryotes in Mobile Bay led McManus et al. (2004) to suggest that grazing, or other loss processes, probably controlled the abundance of prokaryotes within the bay.

To further characterize growth and removal rates for organisms of microbial size in Mobile Bay and the northern Gulf of Mexico, we carried out a series of dilution experiments at 3 sites - from within the bay, at the mouth of the bay, and offshore on the shelf as in Lehrter et al. (1999). In our study, the experiments were done in summer, fall and winter; we measured the rates of growth, grazing and viral lysis in summer (during low river flow) and in winter (with higher river flow). To integrate the effects of viruses into the Mobile Bay system, the rates of grazing and viral lysis were determined for prokaryotes as well as 
for phytoplankton groups using specific pigments as indicators.

\section{MATERIALS AND METHODS}

\section{Sampling}

Surface water was collected from 3 stations along a transect from within Mobile Bay, Alabama, to the shelf in the northern Gulf of Mexico (Fig. 1). Water was immediately filtered through a $150 \mu \mathrm{m}$ nitex screen, to remove large grazers, and was collected in opaque carboys for transport back to the Dauphin Island Sea Lab. Temperature, salinity and dissolved oxygen were measured at each site using a Seabird 911 conductivity, temperature and depth (CTD) profiler. Subsamples were filtered through a muffled $0.7 \mu \mathrm{m}$ glass-fiber filter, and the filtrate was analyzed for $\mathrm{NO}_{3}{ }^{-}+\mathrm{NO}_{2}{ }^{-}, \mathrm{NH}_{4}{ }^{+}, \mathrm{PO}_{4}{ }^{3-}$ and silicon (Si) on a Skalar SAN+ autoanalyzer (Whitledge et al. 1981). Experiments were carried out 3 times - in July and November, 2009, and in January, 2010 - at the shelf station (Compass Port, CP), but only in July and January at the other 2 stations (Dauphin Island, DI, and Middle Bay, MB).

\section{Modified dilution experiments}

Growth rates, along with grazing and viral lysis rates, were estimated using the modified dilution experiment (Evans et al. 2003, Kimmance et al. 2007, Kimmance \& Brussaard 2010). All water processing was carried out in low light, and filtration was carried out under low pressure. All containers were washed in $10 \% \mathrm{HCl}$ and rinsed 3 times with deionized water. The modified dilution experiment includes 2 parallel dilution series, one in which whole water (WW) is diluted with $0.22 \mu \mathrm{m}$ filtered water (Grazing) and one in which WW is diluted with $30 \mathrm{kDa}$ filtered water (Grazing + Viral lysis) (Fig. 2). To set up the experiment, water was passed first through a glass-fiber filter of pore size $0.7 \mu \mathrm{m}$ and then through a Durapore filter (Millipore) of pore size $0.22 \mu \mathrm{m}$ using a peristaltic pump at low speed. Half of the $0.22 \mu \mathrm{m}$ filtered water was kept for the grazer-free dilution series, while the other half was passed through a $30 \mathrm{kDa}$ tangential flow filter to remove viruses for the Grazing and Viral lysis series.

Whole water (WW) for these experiments had been passed through a $150 \mu \mathrm{m}$ screen to remove mesozooplankton. For each dilution series, there were 3 different dilution levels: 30, 50 and $70 \%$ WW. For each treatment (dilution level and dilutant) there were 3 bottles (18 in total). WW was diluted with either $0.22 \mu \mathrm{m}$ or $30 \mathrm{kDa}$ filtered water to produce $4 \mathrm{l}$ of each treatment $(30,50$ and $70 \% \mathrm{WW})$. A volume of 11 was then transferred into 3 clear polycarbonate bottles, leaving $\sim 4 \mathrm{~cm}$ of air in each bottle. Six bottles containing $100 \%$ WW were included for each experiment, 3 with and 3 without nutrients. Nutrients (2 $\mu \mathrm{M} \mathrm{NH} \mathrm{NH}_{4} \mathrm{NO}_{3}$ and $0.1 \mu \mathrm{M} \mathrm{Na} \mathrm{NPO}_{4}$ ) were added to all diluted treatments. Just before starting the

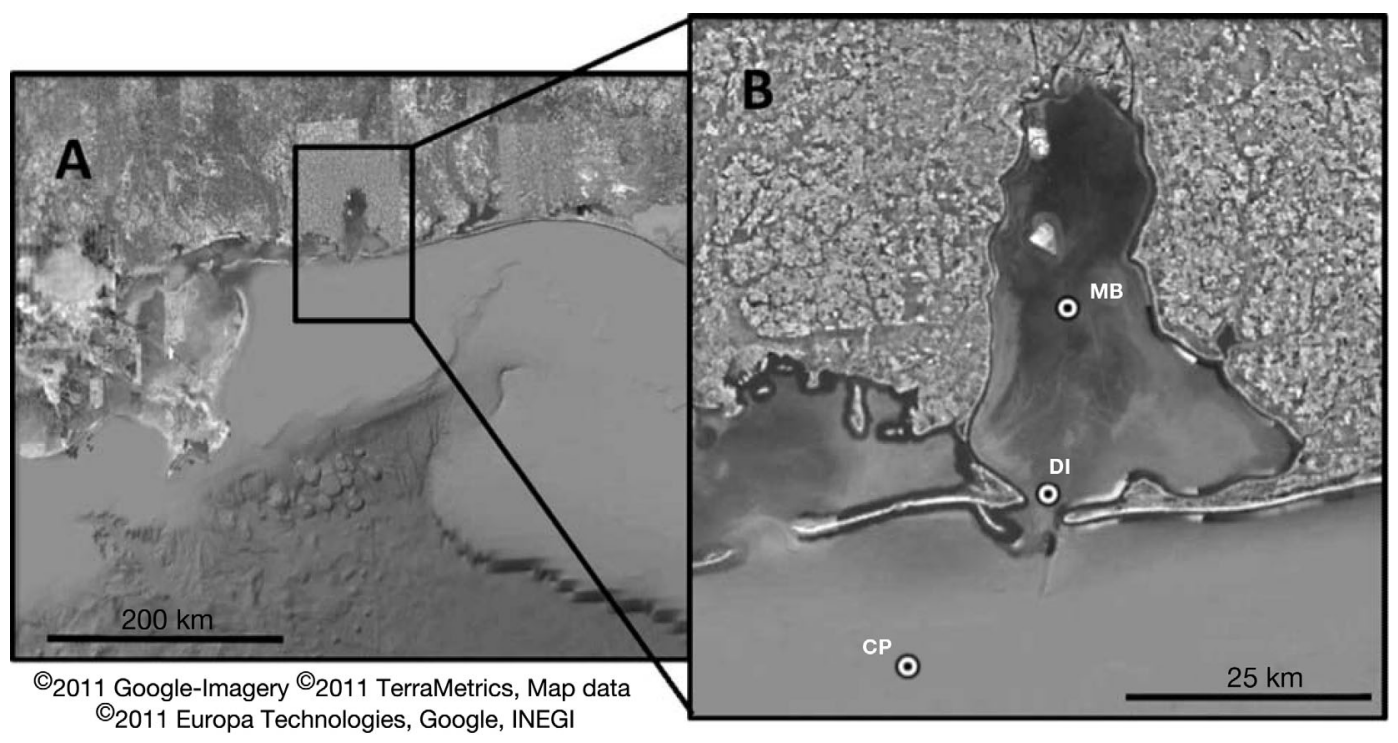

Fig. 1. (A) Northern Gulf of Mexico with the region around Mobile Bay highlighted. (B) The 3 stations sampled from within Mobile Bay to the shelf: MB = Middle Bay, DI = Dauphin Island, CP = Compass Port. Image from Google Earth 


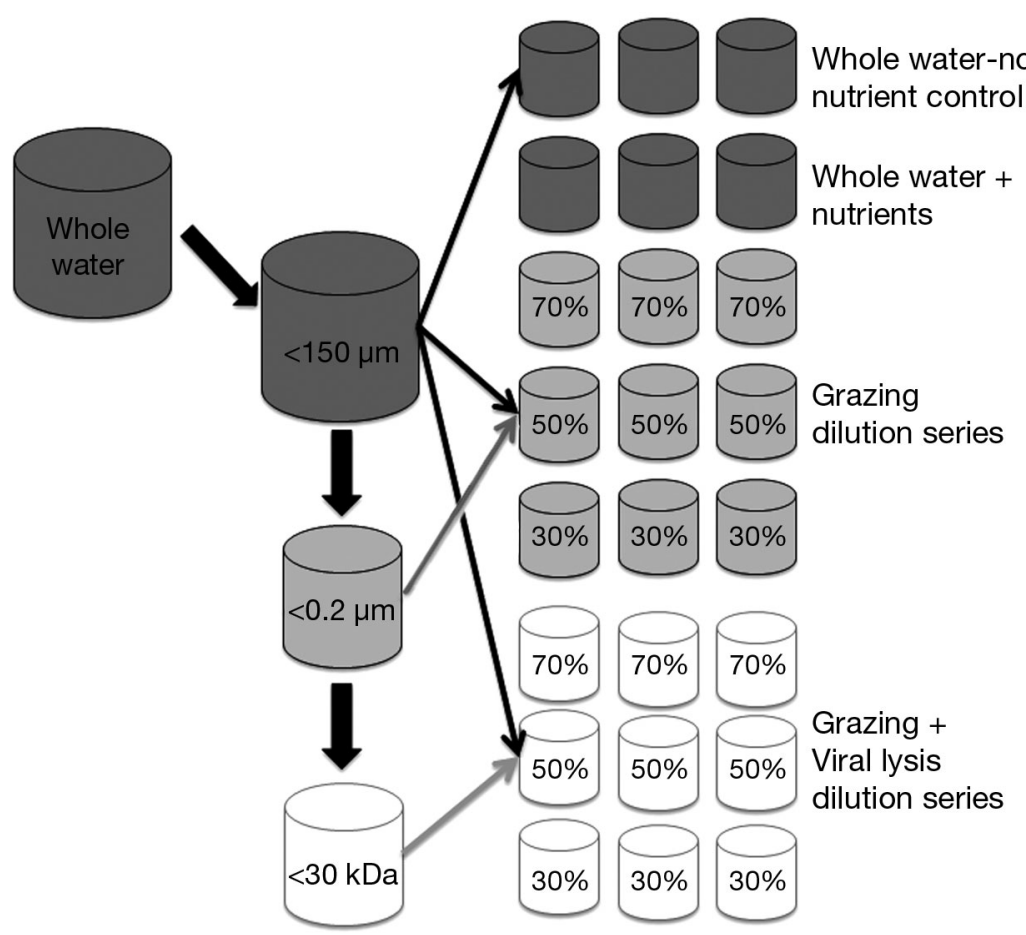

Fig. 2. Schematic of set-up for the modified dilution experiment. Percentages refer to the amount of $<150 \mu \mathrm{m}$ filtered water in the treatment. Nutrients were added to all dilution series bottles as well as to the 3 whole water (WW) bottles indicated. Apparent growth rates were calculated (independently, for each bottle) for prokaryotes and chl $a$, zeaxanthin, fucoxanthin and perdinin were determined

incubation, samples were collected from the volume remaining $(\sim 1$ l) from each treatment $(t=0)$.

The 24 bottles for each experiment were placed in a submersible cage built from PVC pipes and green fencing mesh. The cage was weighted to hold it just below the surface so that experimental bottles would be incubated under similar levels of light from where they were sampled. The cage was shallow enough to prevent the bottles from shading each other, so that all bottles received similar exposure to light. The cage was attached to the dock at the Dauphin Island Sea Laboratory, and bottles were incubated for $22 \mathrm{~h}$. Movement of the water from waves and boat traffic naturally mixed the water in the bottles throughout the incubation period. The water displacement and speed of movement was small relative to the size of the bottles, suggesting that the formation of air bubbles would not severely affect protist cells. In July and November, the difference in temperature between the sample sites and the incubation temperatures was $<2^{\circ} \mathrm{C}_{i}$ however, in January, DI was $\sim 5^{\circ} \mathrm{C}$ cooler than $\mathrm{CP}$, which could have affected the measured rates. Experiments were started near, or just after, dark, so that cells were not suddenly exposed to high levels of sunlight.

\section{Quantifying microbial groups}

Epifluorescence microscopy was used to determine the abundance of viruses and heterotrophic prokaryotes. From each treatment at $\mathrm{t}=0$, and from each bottle at $\mathrm{t}=12$ and $22 \mathrm{~h}$, subsamples of $4.9 \mathrm{ml}$ were collected and added to cryovials containing $100 \mu \mathrm{l}$ of $25 \%$ EM grade glutaraldehyde. Vials were placed at $4^{\circ} \mathrm{C}$ for $15 \mathrm{~min}$ and then flashfrozen in liquid nitrogen. Frozen samples were stored at $-86^{\circ} \mathrm{C}$ until slides could be made for counting prokaryotes and viruses (Wen et al. 2004). Protist slides were also made from these fixed samples, although the abundances may be underestimated as this method of preservation may result in a loss of cells.

To ensure that the viruses were diluted in the Grazing + Viral lysis dilution series, virus abundance was determined for each treatment at $t=0$. A volume of 500 to $800 \mu \mathrm{l}$ of sample was diluted to $1000 \mu \mathrm{l}$ with $0.02 \mu \mathrm{m}$ filtered Nanopure water and filtered onto a $0.02 \mu \mathrm{m}$ Anodisc filter (GE Healthsciences). The sample was stained with SYBR Gold (Invitrogen) and mounted with a DABCO antifade solution (Ortmann \& Suttle 2009). For heterotrophic prokaryotes at $t=0,12$ and $22 \mathrm{~h}, 2 \mathrm{ml}$ of sample was stained with 4', 6-diamidino2-phenylindole (DAPI) and filtered through a black polycarbonate filter of pore size $0.2 \mu \mathrm{m}$ (Porter \& Feig 1980). The filter was dried, and then mounted with DABCO antifade solution. For samples with higher numbers of cells, 0.5 to $1.0 \mathrm{ml}$ of sample was diluted with $(0.02 \mu \mathrm{m}$ filtered) Nanopure water to a volume of $2.0 \mathrm{ml}$ before being stained with DAPI. To estimate the number of protists in WW, $\sim 2.5 \mathrm{ml}$ of fixed sample was stained with DAPI and filtered through a black polycarbonate filter of pore size 1.0 $\mu \mathrm{m}$ (GE Osmonics). Filters were mounted on slides with DABCO antifade solution. The abundance of protists was not determined for the July 2009 samples.

All slides were stored at $-20^{\circ} \mathrm{C}$ until they were counted with an Olympus BH-2 epifluorescence microscope. Following the methods of Ortmann \& Suttle (2009), a minimum of 200 cells/viruses in at least 20 fields were counted for prokaryotes and viruses. When protist numbers were low, a minimum of 50 fields were counted, but total numbers may have been $<200$. 
Phytoplankton biomass was estimated using highperformance liquid chromatography (HPLC) pigment analysis at $\mathrm{t}=0$ and $\mathrm{t}=22 \mathrm{~h}$ (Van Heukelem \& Thomas 2001). Water was filtered through a $25 \mathrm{~mm}$ $0.7 \mu \mathrm{m}$ glass-fiber filter until sufficient color was seen. Because of the limited volume at $t=22 \mathrm{~h}$, some pigments could not be measured in some experiments. Pigments were extracted at $-20^{\circ} \mathrm{C}$ in acetone for $1 \mathrm{~h}$, sonicated, and returned to $-20^{\circ} \mathrm{C}$ for $3 \mathrm{~h}$. All extractions were carried out in the dark. The extracted samples were filtered through a $0.45 \mu \mathrm{m}$ Teflon syringe filter into a scintillation vial. HPLC was performed on this filtrate using an Agilent 1100 HPLC (Agilent Technologies) with a Zorbax Eclipse C8 column. Identification and quantification of chl a, zeaxanthin, fucoxanthin and peridinin was carried out by comparison with purified chlorophyll and carotenoid standards (DHI Laboratory, Horshølm, Denmark). Zeaxanthin was used as a proxy for cyanobacteria, peridinin was a proxy for dinoflagellates, and fucoxanthin was a proxy for diatoms. Fucoxanthin may be found in several groups of phytoplankton, but based on a lack of other marker pigments, diatoms are probably the dominant source of this pigment in this study.

\section{Data analysis}

In situ parameters, including temperature, salinity, river flow, nutrient concentrations and biomass estimates, were compared using Spearman's non-parametric rho $(\rho)$. For most comparisons $n=7$, but $n=5$ for comparisons with peridinin where the pigment was undetectable in CP-July and CP-January.

For each experiment, rates of growth, grazing and viral lysis were determined in individual bottles. The apparent growth rates for prokaryotes, and the 4 pigments described above, were determined by calculating the slope of the change in biomass (the natural log of cell abundance or pigment concentration) over time (h). For phytoplankton, this was the change from $t=0$ to $t=22 h$, while the estimate for prokaryotes was calculated as the slope of the 3 time points collected.

The apparent growth rates $\left(\mathrm{h}^{-1}\right)$ were regressed against the dilution factor for each dilution series. Slopes were considered significant when the p-value of the linear regression was $<0.05$. The slope of significant regressions for the Grazing series was the grazing rate $(\mathrm{g})$. When the slopes of both the Grazing and Grazing + Viral lysis series were significant, an F-test was used to determine whether they were sig- nificantly different at $\alpha=0.05$ (Zar 1999, Kimmance et al. 2007). No viral lysis was recorded when the slopes were not significantly different. For significantly different slopes, the grazing rate was subtracted from the slope of the Grazing + Viral lysis regression to estimate the viral lysis rate (v). The grazing and viral lysis rates were multiplied by -24 to report daily rates.

The intrinsic growth rate $(\mu)$ is usually defined as the actual rate at which the cells are growing, while the apparent growth rate is the rate at which cells are observed to grow in the presence of grazers and viruses. Here, $\mu$ is defined as the growth rate of the cells when no grazing or viral lysis is present. When grazing or lysis was significant, $\mu$ was obtained from the $y$-intercept of the significant regression for either the Grazing or the Grazing + Viral lysis series. When neither slope was significant, $\mu$ was estimated from the rates in the $\mathrm{WW}$ treatments. To compensate for the effects of nutrient addition, the growth in the WW bottles, with and without nutrients, was compared using a 1-tailed $t$-test (Zar 1999). When the addition of nutrients significantly increased the growth rate, the increase was subtracted from the growth rate estimated from the regressions. All growth rates were multiplied by 24 to report daily rates. Net growth $\left(\mu_{\mathrm{Net}}\right)$ was calculated by subtracting total losses $(g+v)$ from the estimated growth rate. The $95 \%$ confidence intervals were calculated for estimates of $\mu, g$ and $v$.

\section{RESULTS}

\section{In situ conditions}

Seven separate experiments were carried out: 3 in the summer, 3 in the winter and 1 during the fall. The 3 stations cover a range of environments from within Mobile Bay (at MB), where the water depth is $3.75 \mathrm{~m}$, to DI at the mouth of the bay, where the water depth is $15 \mathrm{~m}$, and CP, on the shelf, at a water depth of $20 \mathrm{~m}$. Water was collected from just below the surface in the mixed layer. At MB, in both July and January, the mixed layer was only $1.75 \mathrm{~m}$ deep. Mixing at DI was slightly deeper in July (3.5 m) compared to January $(2.5 \mathrm{~m})$. At CP, on the shelf, mixing was $\sim 11 \mathrm{~m}$ in July and January, but only $3.5 \mathrm{~m}$ in November.

Generally, the temperature across the sites was similar at each sample time; however, salinity was always lower inshore, with the lowest salinities at $\mathrm{MB}$ (Fig. 3A). $\mathrm{NH}_{4}{ }^{+}$and $\mathrm{PO}_{4}{ }^{3-}$ were low in most samples and positively correlated $(\rho=0.786, p=0.036)$, 
with slightly higher concentrations in January at $\mathrm{CP}$ and DI (Fig. 3B). $\mathrm{NO}_{3}{ }^{-}$ and dissolved silica (DSi) were higher at all sites in January compared to the July or November samples. DSi was positively correlated with $\mathrm{NH}_{4}{ }^{+}$and $\mathrm{PO}_{4}{ }^{3-}$ ( $\rho=0.8929, p=0.0068$ for both). $\mathrm{NO}_{3}{ }^{-}$ was negatively correlated with temperature $(\rho=-0.9286, p=0.0025)$.

The highest biomass for all groups of microbes was detected in DI-July and MB-July samples (Fig. 4). These samples had the highest level of viruses, prokaryotes and pigments, with the exception of fucoxanthin, which was highest in the $\mathrm{CP}-$ November sample. This peak in fucoxanthin corresponded to the highest DSi concentrations detected at the offshore site. In CP-July, the concentration of fucoxanthin was too low to permit growth and removal rates to be estimated. Peridinin was not detectable at this site in either July or January (CPJuly and CP-January). Across all samples, the abundance of prokaryotes was positively correlated with temperature $(\rho=0.9286, p=0.0025)$, as was the concentration of zeaxanthin $(\rho=0.9643, p=$ 0.0005) and peridinin $(\rho=0.9000, p=$ 0.0374). Prokaryotes and zeaxanthin were negatively correlated with $\mathrm{NO}_{3}{ }^{-}$ $(\rho=-0.8829, p=0.0068$, and $\rho=-0.9643$, $p=0.0005$, respectively). Chlorophyll $a$ was correlated only to the concentration of peridinin $(\rho=0.9000, p=0.0374)$, while fucoxanthin was not correlated with any measured parameter. The abundance of viruses was correlated with $\mathrm{NO}_{3}{ }^{-}(\rho=-0.7857, \mathrm{p}=0.0362)$ and temperature $(\rho=0.7500, p=0.0522)$, showing a pattern similar to that of prokaryotes and zeaxanthin. The abundance of protists was not obtained for July, but estimates from November and January indicated an average of $1.64 \times 10^{7}$ cells $\mathrm{l}^{-1}\left(\right.$ standard deviation $\left.=1.23 \times 10^{7}\right)$.

\section{Modified dilution experiments}

For each experiment, rates of growth, grazing and viral lysis were estimated for 5 different groups of

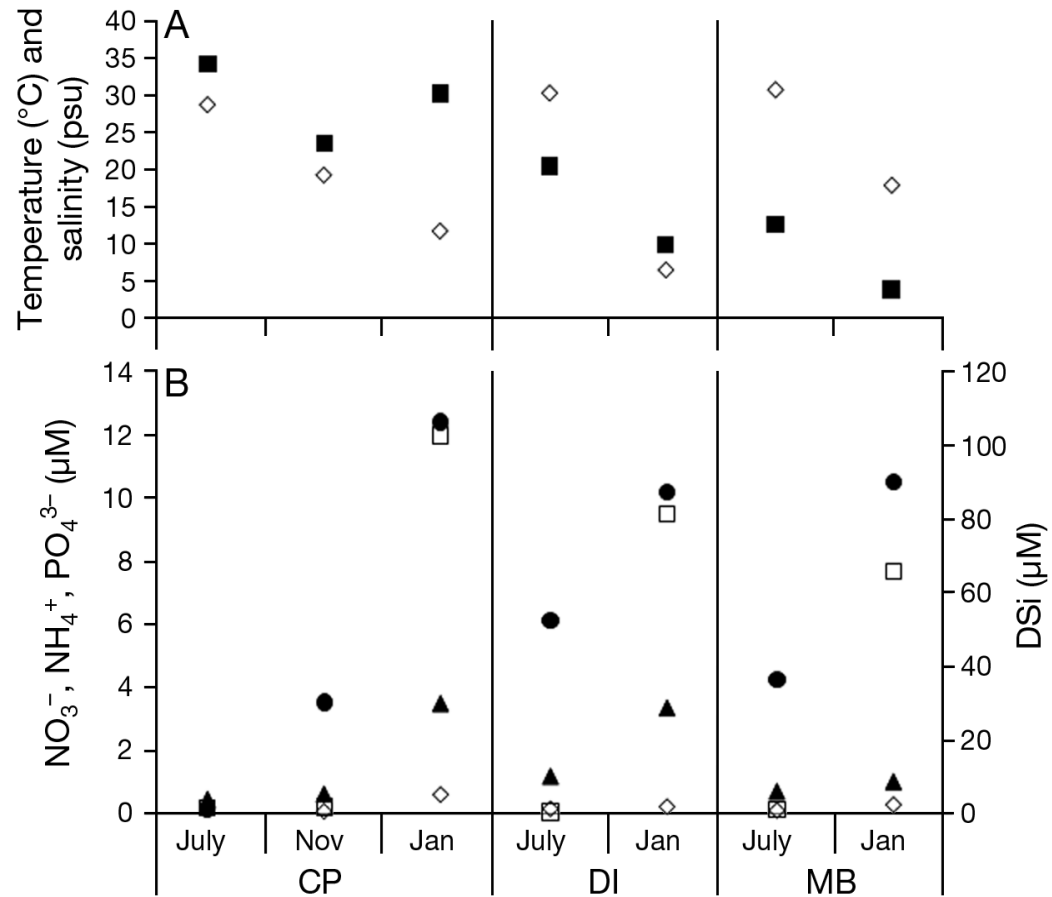

Fig. 3. (A) Temperature $(\diamond)$ and salinity (ם), and (B) nutrient concentrations $-\mathrm{NO}_{3}{ }^{-}(\square), \mathrm{NH}_{4}{ }^{+}(\boldsymbol{\Delta}), \mathrm{PO}_{4}{ }^{3-}(\diamond)$ and DSi $(\bullet)$ - in situ for the 7 experiments. Sampling stations are Compass Port (CP, shelf), Dauphin Island (DI, mouth of the bay) and Middle Bay (MB, within the bay); sampling dates are July and November 2009 and January 2010

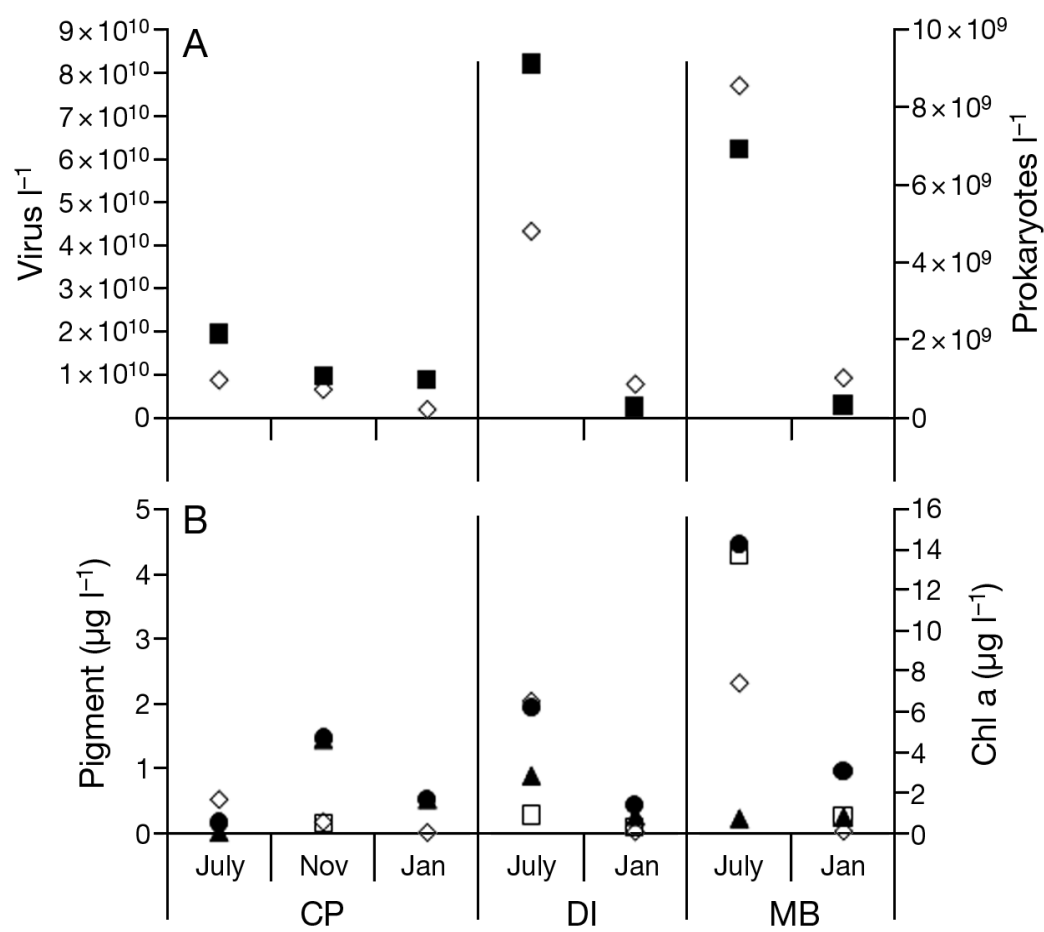

Fig. 4. Biomass estimates at $t=0$ for the 7 experiments. (A) Viruses $(\diamond)$ and prokaryotes (ם). (B) Concentrations of chl a $(\bullet)$, zeaxanthin $(\diamond)$, fucoxanthin $(\boldsymbol{\Lambda})$ and peridinin( $\square$ ). See Fig. 3 for details of sampling stations and dates 
Table 1. p-values for linear regressions of apparent growth rate vs. dilution level. Significant regressions are shown in bold and the number of bottles analyzed for each experiment is shown in parentheses. Chl $a=$ chlorophyll $a$. $\mathrm{CP}=$ Compass Port, $\mathrm{DI}=$ Dauphin Island, and MB = Middle Bay: 3 stations along a transect from within Mobile Bay, Alabama, to the shelf in the northern Gulf of Mexico (see Fig. 1)

\begin{tabular}{|c|c|c|}
\hline Experiment & Grazing (n) & Grazing + Viral lysis (n) \\
\hline \multicolumn{3}{|l|}{ CP-July } \\
\hline Prokaryotes & $0.071(12)$ & $<\mathbf{0 . 0 0 1}(12)$ \\
\hline Chl a & $0.007(12)$ & $0.008(12)$ \\
\hline Zeaxanthin & $0.059(12)$ & $0.149(12)$ \\
\hline \multicolumn{3}{|l|}{ DI-July } \\
\hline Prokaryotes & $0.079(12)$ & $0.072(12)$ \\
\hline $\mathrm{Chl} \mathrm{a}$ & $0.002(12)$ & $0.025(12)$ \\
\hline Zeaxanthin & $0.004(12)$ & $<\mathbf{0 . 0 0 1}(12)$ \\
\hline Fucoxanthin & $0.008(12)$ & $0.091(12)$ \\
\hline Peridinin & $0.161(10)$ & $0.492(9)$ \\
\hline \multicolumn{3}{|l|}{ MB-July } \\
\hline Prokaryotes & $\mathbf{0 . 0 0 9}(12)$ & $0.849(12)$ \\
\hline Chl a & $0.736(12)$ & $0.803(11)$ \\
\hline Zeaxanthin & $<\mathbf{0 . 0 0 1}(12)$ & $0.028(11)$ \\
\hline Fucoxanthin & $<\mathbf{0 . 0 0 1}(12)$ & $0.002(11)$ \\
\hline Peridinin & $0.171(12)$ & $0.315(11)$ \\
\hline \multicolumn{3}{|l|}{ CP-November } \\
\hline Prokaryotes & $0.167(12)$ & $<\mathbf{0 . 0 0 1}(12)$ \\
\hline Chl a & $<\mathbf{0 . 0 0 1}(12)$ & $0.251(12)$ \\
\hline Zeaxanthin & $0.068(10)$ & $0.797(11)$ \\
\hline Fucoxanthin & $0.090(12)$ & $0.518(11)$ \\
\hline Peridinin & $0.142(9)$ & $0.044(10)$ \\
\hline \multicolumn{3}{|l|}{ CP-January } \\
\hline Prokaryotes & $0.013(12)$ & $\mathbf{0 . 0 2 8}(12)$ \\
\hline Chl a & $0.481(12)$ & $0.052(12)$ \\
\hline Zeaxanthin & $\mathbf{0 . 0 1}(12)$ & $0.381(11)$ \\
\hline Fucoxanthin & $0.901(10)$ & $0.692(12)$ \\
\hline \multicolumn{3}{|l|}{ DI-January } \\
\hline Prokaryotes & $<\mathbf{0 . 0 0 1}(12)$ & $\mathbf{0 . 0 1 6}^{\mathrm{a}}(12)$ \\
\hline Chl a & $0.977(12)$ & $0.102(11)$ \\
\hline Zeaxanthin & $0.451(10)$ & 0.629 (10) \\
\hline Fucoxanthin & $0.683(11)$ & $0.048(10)$ \\
\hline Peridinin & $0.079(11)$ & $0.953(10)$ \\
\hline \multicolumn{3}{|l|}{ MB-January } \\
\hline Prokaryotes & $0.198(12)$ & $0.294(12)$ \\
\hline Chl a & $0.158(12)$ & $<\mathbf{0 . 0 0 1}(12)$ \\
\hline Zeaxanthin & $0.616(10)$ & $0.116(9)$ \\
\hline Fucoxanthin & $0.714(12)$ & $0.066(12)$ \\
\hline Peridinin & $0.295(12)$ & $<\mathbf{0 . 0 0 1}(12)$ \\
\hline
\end{tabular}

microbes. Because some pigment concentrations were too low to enable detection with HPLC in 3 cases (CP-July: fucoxanthin and peridinin; CP-January: peridinin), a total of 32 analyses were carried out (Table 1). Linear regression of the apparent growth rate vs. the dilution level for both dilution series resulted in 4 main patterns (Fig. 5, Table 1). For 14 of the 32 analyses, no significant relationship between dilution and growth was seen for either the Grazing or the Grazing + Viral lysis series (Fig. 5A). A significant linear relationship between apparent growth rate and dilution in the Grazing series was detected in 11 analyses (Fig. 5B,D). In 4 cases, only the Grazing regression was significant, while both the Grazing and the Grazing + Viral lysis regressions were significant in 7 cases. The slopes of the 2 lines were not significantly different in 6 of these instances (Fig. 5B), with both grazing and viral lysis detected in only 1 of the 32 analyses (Fig. 5D). For 6 cases, only the regression of the Grazing + Viral lysis series against the dilution level was significant (Fig. 5C). Grazing rates (g) and viral lysis rates (v) were calculated from the slopes of the linear regression along with 95\% confidence intervals (Table 2). For 4 of the 18 estimates of $g$ and $v$, the values were negative due to a positive relationship between apparent growth rate and dilution level.

Two of the estimates of growth and grazing appear to be outliers (Table 2), and represent unrealistic estimates; these values were not included in further analyses. For CP-July, the chl a concentrations were low, even though large volumes (about 3 l) were filtered at $t=0$. Because of the size of the bottles, only ca. $900 \mathrm{ml}$ could be filtered for HPLC analysis at $\mathrm{t}=$ $22 \mathrm{~h}$, and the estimates of chl a were close to the detection limits of the HPLC method. A similar issue was encountered with MB-July for fucoxanthin. In this instance, the starting concentrations at $\mathrm{t}=0$ were close to detection levels, and the increase in the bottles over $22 \mathrm{~h}$ may have resulted in an unrealistically high estimate of growth.

Nutrients were added to all of the bottles containing dilutions, as well as to 3 of the bottles containing WW. A $t$-test was used to compare growth rates in the WW bottles containing added nutrients with growth rates in WW control bottles (which contained no added nutrients). For 5 of the analyses, significantly higher growth was detected in the bottles with added nutrients (Table 2). Four of these analyses were from DI-July, suggesting that primary production was nutrient limited at this site. In the MB-January experiment, zeaxanthin was stimulated by the addition of nutrient. The addition of inorganic nutrients affected growth for prokaryotes only once, in the CP-November sample - in which the growth of prokaryotes was actually depressed by the addition of nutrients.

Total losses $(g+v)$ were calculated and regressed against the estimated growth rate. For 30 analyses, including all microbial groups, there was a signifi- 

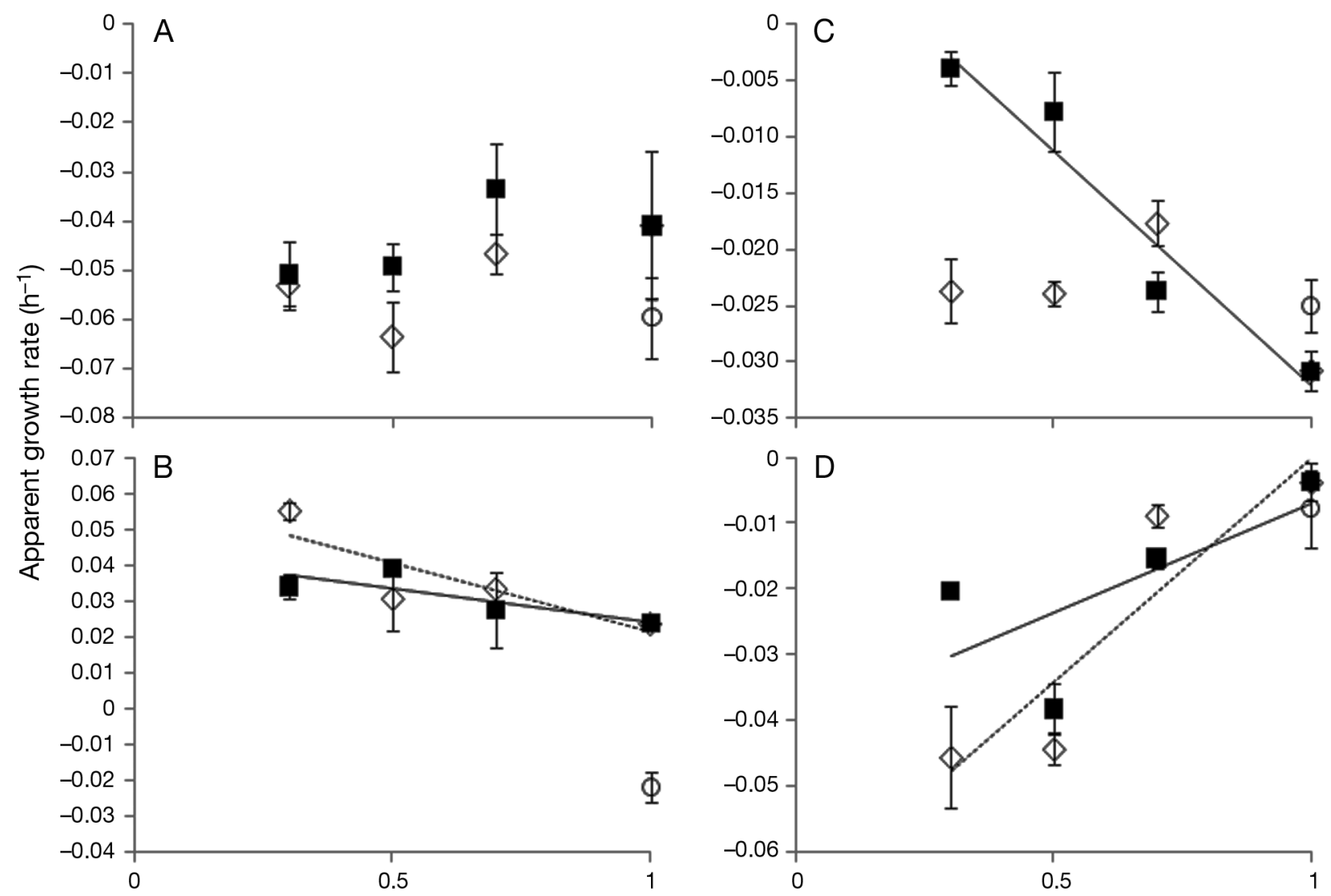

Dilution level

Fig. 5. Examples of apparent growth rates vs. dilution plots. Values are means \pm SD of replicate treatments. (A) No significant relationship, CP (Compass Port)-July 2009, zeaxanthin. (B) Negative slope for Grazing ( $\cdots$ ) and Grazing + Viral lysis (-), DI (Dauphin Island)-July 2009, chlorophyll a. Slopes were not significantly different. (C) Negative slope for Grazing + Viral lysis, CP-November 2009, prokaryotes. (D) Positive slopes for Grazing (‥) and Grazing + Viral lysis (-), DI-January 2010, prokaryotes. Slopes are significantly different. For all plots, $(\diamond)=$ Grazing, $_{(}(\mathbf{\square})=$ Grazing + Viral lysis, and (O) no nutrient controls

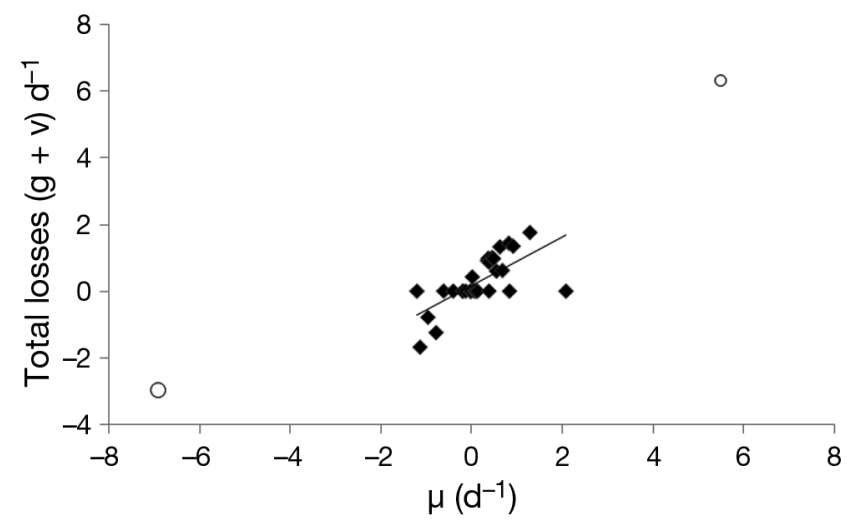

Fig. 6. Growth rate estimated from the $y$-intercept of the dilution regression vs. total removal rates $(g+v)$ for 30 analyses. CP(Compass Port)-July chlorophyll a and MB(Middle Bay)-July fucoxanthin data were not included in the analysis but are shown as open symbols. A significant linear regression indicates a positive relationship between growth and loss for these experiments (total loss rate $=0.73 \mu$ $+0.17, \mathrm{p}<0.001, \mathrm{R}^{2}=0.45$ ) cant positive relationship between losses and growth $\left(\mathrm{R}^{2}=0.45, \mathrm{p}<0.001\right)$ (Fig. 6). This relationship was weak, with the strongest relationships for $\mathrm{chl} a\left(\mathrm{R}^{2}=\right.$ 0.88, $\mathrm{p}=0.0058)$ and zeaxanthin $\left(\mathrm{R}^{2}=0.72, \mathrm{p}=\right.$ 0.0151). Environmental variables did not explain most of the variability in the growth rates. For chl $a_{1} \mu$ was negatively correlated with both $\mathrm{PO}_{4}{ }^{3-}$ and DSi ( $\rho=-0.9429, p=-0.048, n=6$ for both), while $\mu$ for peridinin was positively correlated with salinity $(\rho=$ $0.900, p=0.0374, n=5$ ). Growth of prokaryotes and changes in zeaxanthin and fucoxanthin concentrations were not significantly correlated with any of the measured parameters.

To determine groups and samples in which biomass could be accumulating we calculated the net growth rate $\left(\mu_{\mathrm{Net}}=\mu-(\mathrm{g}+\mathrm{v})\right)$ (Table 3$)$. In 9 analyses, the estimated $\mu_{\text {Net }}$ was positive, with all but 2 cases (CP-January, fucoxanthin and DI-July, peridinin) detected in incubations from MB. For 12 
Table 2. Growth rate $(\mu)$, grazing rate $(\mathrm{g})$ and viral lysis rate $(\mathrm{v})$ for each experiment $\left(\mathrm{d}^{-1}\right)$ with the $95 \%$ confidence interval $(\mathrm{CI})$ for each parameter. Growth rates in bold were derived from the $y$-intercept of the linear regression. Non-bold values are averages of growth in the whole water (WW) treatments. Chl $a=$ chlorophyll $a$. For details of stations $\mathrm{CP}$, DI and MB see the legend of Table 1

\begin{tabular}{|c|c|c|c|c|c|c|}
\hline Experiment & $\mu$ & $95 \% \mathrm{CI}$ & g & $95 \% \mathrm{CI}$ & $\mathrm{v}$ & $95 \% \mathrm{CI}$ \\
\hline \multicolumn{7}{|l|}{ CP-July } \\
\hline Prokaryotes & 0.818 & $(0.433,1.203)$ & 0 & & 1.447 & $(0.88,2.014)$ \\
\hline Chl $a^{b}$ & $-6.912^{\mathrm{a}}$ & $(-7.7,-6.124)$ & -2.954 & $(-4.911,-0.997)$ & 0 & \\
\hline Zeaxanthin & -1.205 & $(-1.562,-0.848)$ & 0 & & 0 & \\
\hline \multicolumn{7}{|l|}{ DI-July } \\
\hline Prokaryotes & -0.617 & $(-0.751,-0.483)$ & 0 & & 0 & \\
\hline Chl a & $0.346^{\mathrm{a}}$ & $(0.184,0.507)$ & 0.929 & $(0.437,1.421)$ & 0 & \\
\hline Zeaxanthin & $0.382^{\mathrm{a}}$ & $(0.253,0.511)$ & 0.878 & $(0.338,1.418)$ & 0 & \\
\hline Fucoxanthin & $0.449^{\mathrm{a}}$ & $(0.235,0.663)$ & 1.015 & $(0.331,1.7)$ & 0 & \\
\hline Peridinin & $2.076^{\mathrm{a}}$ & $(1.65,2.502)$ & 0 & & 0 & \\
\hline \multicolumn{7}{|l|}{ MB-July } \\
\hline Prokaryotes & 0.677 & $(0.388,0.966)$ & 0.624 & $(0.191,1.057)$ & 0 & \\
\hline $\mathrm{Chl} \mathrm{a}$ & 0.382 & $(0.211,0.552)$ & 0 & & 0 & \\
\hline Zeaxanthin & 1.282 & $(0.897,1.667)$ & 1.771 & $(1.204,2.338)$ & 0 & \\
\hline Fucoxanthin $^{\mathrm{b}}$ & 5.491 & $(4.288,6.694)$ & 6.336 & $(4.555,8.117)$ & 0 & \\
\hline Peridinin & 0.128 & $(-0.067,0.324)$ & 0 & & 0 & \\
\hline \multicolumn{7}{|l|}{ CP-November } \\
\hline Prokaryotes & $0.365^{\mathrm{a}}$ & $(0.286,0.443)$ & 0 & & 0.996 & $(0.777,1.215)$ \\
\hline Chl a & 0.912 & $(0.543,1.281)$ & 1.358 & $(0.813,1.904)$ & 0 & \\
\hline Zeaxanthin & -0.13 & $(-0.209,-0.05)$ & 0 & & 0 & \\
\hline Fucoxanthin & -0.194 & $(-0.345,-0.043)$ & 0 & & 0 & \\
\hline Peridinin & 0.482 & $(-0.149,1.113)$ & 0 & & 0.984 & $(0.043,1.925)$ \\
\hline \multicolumn{7}{|l|}{ CP-January } \\
\hline Prokaryotes & 0.622 & $(-0.042,1.285)$ & 1.334 & $(0.351,2.318)$ & 0 & \\
\hline $\mathrm{Chl} \mathrm{a}$ & -0.029 & $(-0.18,0.122)$ & 0 & & 0 & \\
\hline Zeaxanthin & 0.014 & $(-0.189,0.218)$ & 0.427 & $(0.128,0.727)$ & 0 & \\
\hline Fucoxanthin & 0.055 & $(-0.096,0.206)$ & 0 & & 0 & \\
\hline \multicolumn{7}{|l|}{ DI-January } \\
\hline Prokaryotes & -0.962 & $(-1.374,-0.551)$ & -1.639 & $(-2.217,-1.062)$ & 0.847 & $(0.011,1.683)$ \\
\hline $\mathrm{Chl} \mathrm{a}$ & -0.012 & $(-0.099,0.075)$ & 0 & & 0 & \\
\hline Zeaxanthin & -0.194 & $(-0.261,-0.128)$ & 0 & & 0 & \\
\hline Fucoxanthin & 0.547 & $(0.171,0.924)$ & 0 & & 0.605 & $(0.007,1.203)$ \\
\hline Peridinin & -0.405 & $(-1.532,0.722)$ & 0 & & 0 & \\
\hline \multicolumn{7}{|l|}{ MB-January } \\
\hline Prokaryotes & 0.833 & $(0.601,1.065)$ & 0 & & 0 & \\
\hline Chl a & -0.782 & $(-1.146,-0.49)$ & 0 & & -1.253 & $(-1.788,-0.718)$ \\
\hline Zeaxanthin & $-0.024^{\mathrm{a}}$ & $(-0.038,-0.01)$ & 0 & & 0 & \\
\hline Fucoxanthin & 0.091 & $(0.005,0.178)$ & 0 & & 0 & \\
\hline Peridinin & -1.137 & $(-1.62,-0.653)$ & 0 & & -1.692 & $(-2.409,-0.975)$ \\
\hline
\end{tabular}

other analyses, the $95 \%$ confidence intervals span positive estimates of $\mu_{\mathrm{Net}}$, suggesting that, in the majority of samples, an accumulation of biomass was possible. For 9 analyses, the maximum $\mu_{\text {Net }}$ estimates were negative, with estimates of zeaxanthin growth comprising 5 of these cases. More than half of the estimates of $\mu_{\mathrm{Net}}$ for $\mathrm{CP}$ were negative (6 of 11 estimates), while most of the estimates from DI (7/10) and MB (8/9) were positive.

\section{DISCUSSION}

\section{In situ conditions}

The 7 experiments were carried out during 3 different seasons, with temperature reflecting these differences (Fig. 3). However, patterns in salinity, nutrients and mixed layer depth were consistent across the stations in both July and January. CP, on 
Table 3. Net growth rates $\left(\mu_{\text {Net }}=\mu-(g+v) ; d^{-1}\right)$. Bold indicates the estimates where there were positive net growth rates suggesting an accumulation of biomass at these sites and times. Chl $a=$ chlorophyll $a$. $\mathrm{CI}=$ confidence interval. For details of stations $\mathrm{CP}, \mathrm{DI}$ and $\mathrm{MB}$ see the legend of Table 1

\begin{tabular}{|c|c|c|}
\hline Experiment & $\mu_{\mathrm{Net}}$ & $95 \% \mathrm{CI}$ \\
\hline \multicolumn{3}{|l|}{ CP-July } \\
\hline Prokaryotes & -0.629 & $(-1.314,0.056)$ \\
\hline Zeaxanthin & -1.205 & $(-1.562,-0.848)$ \\
\hline \multicolumn{3}{|l|}{ DI-July } \\
\hline Prokaryotes & -0.617 & $(-0.751,-0.483)$ \\
\hline Chl a & -0.583 & $(-1.101,-0.065)$ \\
\hline Zeaxanthin & -0.496 & $(-1.052,0.058)$ \\
\hline Fucoxanthin & -0.566 & $(-1.283,0.151)$ \\
\hline Peridinin & 2.076 & $(1.65,2.502)$ \\
\hline \multicolumn{3}{|l|}{ MB-July } \\
\hline Prokaryotes & 0.053 & $(-0.468,0.574)$ \\
\hline Chl a & 0.382 & $(0.212,0.552)$ \\
\hline Zeaxanthin & -0.489 & $(-1.175,0.195)$ \\
\hline Peridinin & 0.128 & $(-0.067,0.323)$ \\
\hline \multicolumn{3}{|l|}{ CP-November } \\
\hline Prokaryotes & -0.631 & $(-0.864,-0.398)$ \\
\hline Chl a & -0.446 & $(-1.104,0.212)$ \\
\hline Zeaxanthin & -0.130 & $(-0.209,-0.051)$ \\
\hline Fucoxanthin & -0.194 & $(-0.345,-0.043)$ \\
\hline Peridinin & -0.502 & $(-1.635,0.631)$ \\
\hline \multicolumn{3}{|l|}{ CP-January } \\
\hline Prokaryotes & -0.712 & $(-1.899,0.473)$ \\
\hline $\mathrm{Chl} \mathrm{a}$ & -0.029 & $(-0.18,0.122)$ \\
\hline Zeaxanthin & -0.413 & $(-0.775,-0.051)$ \\
\hline Fucoxanthin & 0.055 & $(-0.096,0.206)$ \\
\hline \multicolumn{3}{|l|}{ DI-January } \\
\hline Prokaryotes & -0.170 & $(-1.266,0.926)$ \\
\hline Chl a & -0.012 & $(-0.099,0.075)$ \\
\hline Zeaxanthin & -0.194 & $(-0.26,-0.128)$ \\
\hline Fucoxanthin & -0.058 & $(-0.764,0.648)$ \\
\hline Peridinin & -0.405 & $(-1.532,0.722)$ \\
\hline \multicolumn{3}{|l|}{ MB-January } \\
\hline Prokaryotes & 0.833 & $(0.601,1.065)$ \\
\hline Chl a & 0.471 & $(-0.177,1.117)$ \\
\hline Zeaxanthin & -0.024 & $(-0.038,-0.01)$ \\
\hline Fucoxanthin & 0.091 & $(0.005,0.177)$ \\
\hline Peridinin & 0.555 & $(-0.309,1.419)$ \\
\hline
\end{tabular}

the shelf, represented a higher salinity, lower nutrient site compared with DI at the mouth of the bay and $\mathrm{MB}$ inside the bay. Mixing was shallow within the bay and at the bay mouth. On the shelf, the mixed layer in November was very shallow, probably due to the high river discharge at that time. River discharge strongly influenced the concentration of $\mathrm{NO}_{3}{ }^{-}$, but did not appear to have the same affect on $\mathrm{NH}_{4}{ }^{+}, \mathrm{PO}_{4}{ }^{3-}$ or DSi. It is possible that these nutrients are controlled by recycling within the bay and on the shelf rather than through delivery by the rivers.
As in a previous study in Mobile Bay (McManus et al. 2004), temperature was found to be positively correlated with the abundance of prokaryotes, with much higher numbers present during July than in January. Zeaxanthin, a proxy for cyanobacteria, and peridinin, a proxy for dinoflagellates, were also positively correlated with temperature. These correlations agree with patterns observed in Pensacola Bay, a river-dominated estuary $\sim 80 \mathrm{~km}$ east of Mobile Bay (Murrell \& Lores 2004). Over a period of $2 \mathrm{yr}$, zeaxanthin and peridinin were both found to have the highest concentrations within Pensacola Bay during the summer months. These observations were confirmed through microscopy and flow cytometry. In this study, zeaxanthin was the dominant accessory pigment detected in CP-July, and was a significant component of the pigments at DIJuly, although fucoxanthin was also a major pigment at DI-July. In MB-July, zeaxanthin was also high, but peridinin was the dominant pigment. This suggests that dinoflagellates were more abundant within the bay in the summer, while diatoms increased at the mouth of the bay, and cyanobacteria dominated the shelf region. Fucoxanthin was found to increase in concentration in the fall and through the winter in Pensacola Bay; this agrees with the peak in fucoxanthin detected at $\mathrm{CP}$ in November, suggesting that diatoms dominated in the fall. For all of these samples, other phytoplankton (i.e. chlorophytes) were also probably present based on the detection of other accessory pigments (lutein and chl $b$ ) in some samples.

\section{Modified dilution experiments}

From the 7 modified dilution experiments carried out, we obtained 32 estimates of $\mu, g, v$ and $\mu_{\text {Neti }}$ however, 2 of these analyses resulted in unrealistic estimates of growth (Table 2). Both of these analyses were probably influenced by low concentrations of the specific pigments and were excluded from further analysis.

Four main patterns of grazing and viral lysis were observed for these 7 experiments (Fig. 5). In most cases (14 analyses), neither grazing nor viral lysis was detected. This pattern was seen in all experiments and was seen for all 5 groups of microbes, but these analyses did not share one common trait. Estimates of $\mu_{\mathrm{Net}}$ for these analyses suggest that, for 9 of these instances, a net increase in biomass was possible, although estimates of growth rate for most of these organisms were close to zero. Low growth rates 
in these organisms may lead to very low rates of grazing and viral lysis, well below the level of detection of the modified dilution experiments (Kimmance et al. 2007).

\section{Grazing and viral lysis}

Grazing alone was detected in 8 of the analyses, while only viral lysis was detected in 7 analyses (Table 2). There was only 1 case in which both grazing and viral lysis were detected - for prokaryotes in the DI-January experiment. Also, there did not appear to be any seasonal or environmental factor that was related to grazing or viral lysis in these experiments. Other studies have tried to connect the prevalence of one or the other process to the trophic status of the environment (Zhang et al. 2007, Berdjeb et al. 2011), with a greater effect of grazers in oligotrophic, low-productivity environments, and a larger effect of viruses in more eutrophic environments in which larger grazers may reduce the effects of microzooplankton (Pernthaler 2005). In this study, viral lysis of prokaryotes was detected in the CP-July experiment in which in situ conditions indicated oligotrophic conditions with low biomass and low concentrations of inorganic nutrients. In July, grazing appeared to be the main factor in removing phytoplankton and prokaryotes inshore, where the high biomass indicates mesotrophic to eutrophic conditions. The lack of a clear pattern between grazing and viral lysis and biomass or inorganic nutrients in this study suggests that trophic status is not a good indicator of whether grazing or viral lysis may dominate at a given site.

As mentioned above, the single analysis in which both grazing and viral lysis were detected was for prokaryotes in the DI-January sample (Table 2). This is also one of the 3 instances in which significant linear regressions resulted in positive slopes, and thus negative estimates of grazing or viral lysis. The interpretation of positive slopes in dilution experiments is troublesome (Juhl \& Murrell 2005, Tijdens et al. 2008, Chen \& Liu 2010). The measured apparent growth rate in the experimental treatments is assumed to be due to changes in grazing/lysis, with dilution of predators while the intrinsic growth rate of the prey remains constant (Landry \& Hassett 1982). The increasing apparent growth rate with increased potential predation suggests that the growth rate of the prey is changing, which violates an assumption of the experiment (Tijdens et al. 2008). This also means that the $y$-intercept, usually interpreted as the intrin- sic growth rate of the organisms, must be interpreted differently. In this instance, the $y$-intercept would represent the growth rate in the absence of grazers and viruses, and the intrinsic growth rate would be better estimated from growth in the undiluted incubations.

The detection of this pattern in our experiments, and in those of others, suggests a biological basis to this result. One interpretation of this pattern is that stimulation of growth is due to recycling of nutrients by grazers or viruses. For prokaryotes in DIJanuary, grazing appeared to release DOM, increasing the growth rate for this group. Viral lysis resulted in a decrease in the slope (Fig. 5D), suggesting that this process was acting to reduce the apparent growth rate, thus the viral lysis rate is positive. In this same sample, grazing was also found to be significant for zeaxanthin, so it is possible that grazing on cyanobacteria was releasing some of the DOM to stimulate growth of prokaryotes. In the MB-January samples, viral lysis was found to positively affect growth of both total phytoplankton (chl a) and dinoflagellates (peridinin). Neither of these pigments was found to be nutrient limited in this experiment, so it is unlikely that viral lysis was able to stimulate growth by releasing inorganic $\mathrm{N}$ or $\mathrm{P}$, although it is possible that other nutrients (i.e. trace metals) were limiting. For all 3 of these analyses, the estimated $\mu_{\mathrm{Net}}$ (Table 3) was not significantly different from the estimated growth rates in the WW bottles. For DIJanuary, the prokaryotes $\mu_{\mathrm{Net}}\left(\mathrm{d}^{-1}\right.$, plus CI)was $-0.170(-1.266$ to 0.926$)$, while growth in the WW was $-0.139(-0.255$ to -0.027$)$. Growth of total phytoplanktion (chl a) $(0.571,0.363$ to 0.780$)$ and dinoflagellates (peridinin) $(0.3816,0.211$ to 0.552$)$ in the WW bottles for MB-January also overlapped with the estimates of $\mu_{\mathrm{Net}}(0.471,-0.177$ to 1.117 and $0.555,-0.309$ to 1.419$)$, suggesting that viral lysis was stimulating growth of these groups in this experiment.

\section{Addition of nutrients}

In these experiments, nutrients were added to all the treatment bottles, although an effect was seen in only 5 of the 30 analyses (Table 2), suggesting that limitation by $\mathrm{N}$ and $\mathrm{P}$ was not occurring at these sites when the samples were collected. The one site that was clearly nutrient limited was the DI location in July. Growth of all the phytoplankton measured was significantly stimulated by the addition of $\mathrm{N}$ and $\mathrm{P}$. 
Concentrations of inorganic nutrients were low in July compared to January, and a very low river discharge was probably responsible for the low delivery rates of nutrients. In these samples, grazing was detected for total phytoplankton ( $\mathrm{chl}$ a), cyanobacteria (zeaxanthin) and diatoms (fucoxanthin), but not for dinoflagellates (peridinin). The high estimated growth rates for dinoflagellates (peridinin) would suggest that dinoflagellates were not only able to compete for the nutrients available, but lacked a predator to keep their abundance low. It is also possible that heterotrophy by dinoflagellates helped to support the high growth rates. The increased growth of cyanobacteria (zeaxanthin) in the MB-January experiment in response to nutrients may reflect the tight coupling between viral lysis and growth of total phytoplankton (chl a) and dinoflagellates (peridinin) in this sample. The release of nutrients through viral lysis appears to stimulate the growth of phytoplankton, especially dinoflagellates, suggesting some nutrient limitation at the $\mathrm{MB}$ site at this time. Although viral lysis of cyanobacteria was not detected in this experiment, the growth of this group does appear to be limited as well.

In CP-November, prokaryote growth was actually decreased by the addition of inorganic nutrients $\left(\mu_{\text {Nutrient }}=-0.739, \mu_{\text {No Nutrients }}=-0.599 \mathrm{~d}^{-1}\right)$. None of the accessory pigments in this experiment were significantly affected by the nutrients. The addition of inorganic nutrients did not affect the growth of prokaryotes in any of the other experiments, suggesting that prokaryote growth was probably controlled by temperature and not by the availability of food (McManus et al. 2004).

\section{Patterns of growth, grazing and viral lysis}

Positive $\mu_{\text {Net }}$ values were detected most often at $\mathrm{MB}$, regardless of the time of year. This is the site within the bay where nutrient inputs would be expected to be highest. This pattern is the opposite of that previously detected in Mobile Bay, where average growth and grazing of phytoplankton ( $\mathrm{chl}$ a) was found to be lowest within the bay ( $\mu=-0.09$ to 2.06 , $\mathrm{g}=0.05$ to $\left.0.96 \mathrm{~d}^{-1}\right)$ and to increase offshore $(\mu=0.01$ to $3.45, g=-0.09$ to $2.93 \mathrm{~d}^{-1}$ ) (Lehrter et al. 1999). Variability in the estimates increased from the bay to offshore, with large variation between months. In our experiments, grazing was not detected for chl a within the bay, but viral lysis had a positive effect on growth in January. Moving off shore, grazing was detected at DI in July and CP in November, but not at either station in January. No estimate of grazing at $\mathrm{CP}$ in July was obtained due to low pigment concentrations, but our data do agree with an increase in chl a grazing rates across the shelf compared to within the bay.

A different pattern emerges when examining the grazing and lysis rates on accessory pigments. For zeaxanthin, grazing was higher in the bay in July, but higher offshore in January. This difference is probably due to variation in the proportion of grazers that are able to consume small cyanobacterial cells, or due to higher abundances of cyanobacteria within Mobile Bay in the summer. Although viruses infecting cyanobacteria are commonly found in marine waters (Suttle \& Chan 1993, 1994, Long et al. 2008), lysis of cyanobacteria was not detected. For peridinin, grazing was never detected; however, viral lysis may play a role in controlling the abundance and growth of this group. In contrast to both zeaxanthin and peridinin, fucoxanthin appears to be controlled by both grazing and viral lysis, although at different times of the year. In July, when biomass was high and grazers were also probably more abundant, grazing was the main removal process for fucoxanthin, while in January, with lower temperatures and biomass, viral lysis became important.

The estimates for growth, grazing and viral lysis in these experiments were based on changes in pigment concentrations rather than on changes in cell number. Because light conditions at the incubation site may have differed from those at the sampling location, the per-cell pigment concentrations could have changed in our incubations. Although a shift in the concentration of pigments per cell could alter the actual estimates of growth, grazing and viral lysis rates, the patterns in grazing and viral lysis should not change.

Modified dilution experiments have rarely been used to measure grazing and viral lysis for prokaryotes; however, several studies have applied them in both fresh and marine waters (Jacquet et al. 2005, Personnic et al. 2009, Chen et al. 2011, Thomas et al. 2011). A potential concern with using these experiments is that a reduction in grazing and/or viral lysis could result in a decrease in DOM and a limitation of food for prokaryotes. This limitation would result in a negative estimate for grazing and/or lysis, which occurred only once in this experiment. Like fucoxanthin, both grazing and viral lysis appear to control the abundance of prokaryotes. Grazing for prokaryotes was detected on 3 different occasions, once at each station, with viral lysis detected twice at CP and once at DI. With the exception of DI-January, discussed 
above, grazing and viral lysis resulted in a decrease in the apparent growth rate of prokaryotes. The results of this study support the suggestion that prokaryotes are not nutrient limited within Mobile Bay (McManus et al. 2004).

Both grazing and viral lysis appear to be common within Mobile Bay and the northern Gulf of Mexico. For phytoplankton, grazing appears to be more common in the summer, with all but one of the estimates of phytoplankton grazing coming from July experiments. This is likely when microzooplankton are most abundant and also when the biomass of phytoplankton is highest. The dominance of protist grazing in the summer suggests that the Mobile Bay estuary has a more efficient food web at the time when the most larvae and juveniles would be inshore (Szedlmayer \& Conti 1999, Heck et al. 2001). Because protist grazing transfers production from small phytoplankton and prokaryotes to higher trophic levels, rather than shunting it into the dissolved pool through viral lysis, protist grazing is important in supporting the high biomass of higher trophic species, especially larvae and juveniles of fish using the estuary as a nursery. In winter months, recycling of nutrients through viral lysis may be an important contributor to supporting the growth of phytoplankton in the Mobile Bay system. The variability in growth, grazing and viral lysis between chl a estimates, and those for the specific pigments, highlights the differences between groups of phytoplankton. Although bulk measurements, such as chl $a$, can provide some information about a system, it is important to look separately at the different components to fully understand how a system functions.

Acknowledgements. The authors thank the FOCAL group for sample collection and L. Linn for analysis of nutrients. This project was supported by funding from DISL, through the Shelby Center for Ecosystem Based Fisheries Management supported by NOAA NA06NMF4690223.

\section{LITERATURE CITED}

Baudoux AC, Noordeloos AAM, Veldhuis MJW, Brussaard CPD (2006) Virally induced mortality of Phaeocystis globosa during two spring blooms in temperate coastal waters. Aquat Microb Ecol 44:207-217

Baudoux AC, Veldhuis MJW, Noordeloos AAM, van Noort G, Brussaard CPD (2008) Estimates of virus- vs. grazing induced mortality of picophytoplankton in the North Sea during summer. Aquat Microb Ecol 52:69-82

Berdjeb L, Pollet T, Domaizon I, Jacquet S (2011) Effect of grazers and viruses on bacterial community structure and production in two contrasting trophic lakes. BMC Microbiol 11:88
Bonilla-Findji O, Herndl GJ, Gattuso JP, Weinbauer MG (2009) Viral and flagellate control of prokaryotic production and community structure in offshore Mediterranean waters. Appl Environ Microbiol 75:4801-4812

- Boras JA, Sala MM, Vázquez-Domínguez E, Weinbauer MG, Vaqué D (2009) Annual changes of bacterial mortality due to viruses and protists in an oligotrophic coastal environment (NW Mediterranean). Environ Microbiol 11:1181-1193

> Chen B, Liu H (2010) Trophic linkages between grazers and ultraplankton within the microbial food web in subtropical coastal waters. Mar Ecol Prog Ser 407:43-53

> Chen X, Liu H, Weinbauer M, Chen B, Jiao N (2011) Viral dynamics in the surface water of the western South China Sea in summer 2007. Aquat Microb Ecol 63: 145-160

de Figueiredo GM, Nash RDM, Montagnes DJS (2005) The role of the generally unrecognised microprey source as food for larval fish in the Irish Sea. Mar Biol 148:395-404

$>$ Evans C, Archer SD, Jacquet S, Wilson WH (2003) Direct estimates of the contribution of viral lysis and microzooplankton grazing to the decline of a Micromonas spp. population. Aquat Microb Ecol 30:207-219

First MR, Lavrentyev PJ, Jochem FJ (2007) Patterns of microzooplankton growth in dilution experiments across a trophic gradient: implications for herbivory studies. Mar Biol 151:1929-1940

> Fuhrman JA (1999) Marine viruses and their biogeochemical and ecological effects. Nature 399:541-548

Fukami K, Watanabe A, Fujita S, Yamaoka K, Nishijima T (1999) Predation on naked protozoan microzooplankton by fish larvae. Mar Ecol Prog Ser 185:285-291

Garza DR, Suttle CA (1995) Large double-stranded DNA viruses which cause the lysis of a marine heterotrophic nanoflagellate (Bodo sp.) occur in natural marine viral communities. Aquat Microb Ecol 9:203-210

- Gonzalez JM, Suttle CA (1993) Grazing by marine nanoflagellates on viruses and virus-sized particles: ingestion and digestion. Mar Ecol Prog Ser 94:1-10

> Guixa-Boixereu N, Lysnes K, Pedros-Alio C (1999) Viral lysis and bacterivory during a phytoplankton bloom in a coastal water microcosm. Appl Environ Microbiol 65: 1949-1958

Heck KL Jr, Coen LD, Morgan SG (2001) Pre- and postsettlement factors as determinants of juvenile blue crab Callinectes sapidus abundance: results from the north-central Gulf of Mexico. Mar Ecol Prog Ser 222: 163-176

Jacquet S, Domaizon I, Personnic S, Ram ASP, Hedal M, Duhamel S, Sime-Ngando T (2005) Estimates of protozoan- and viral-mediated mortality of bacterioplankton in Lake Bourget (France). Freshw Biol 50:627-645

$>$ Juhl AR, Murrell MC (2005) Interactions between nutrients, phytoplankton growth, and microzooplankton grazing in a Gulf of Mexico estuary. Aquat Microb Ecol 38:147-156

> Karuza A, Del Negro P, Crevatin E, Fonda Umani S (2010) Viral production in the Gulf of Trieste (Northern Adriatic Sea): preliminary results using different methodological approaches. J Exp Mar Biol Ecol 383:96-104

Kimmance SA, Brussaard CPD (2010) Estimation of viralinduced phytoplankton mortality using the modified dilution method. In: Wilhelm SW, Weinbauer MG, Suttle CA (eds) Manual of aquatic viral ecology. ASLO, Waco, TX, p 65-73 
Kimmance SA, Wilson WH, Archer SD (2007) Modified dilution technique to estimate viral versus grazing mortality of phytoplankton: limitations associated with method sensitivity in natural waters. Aquat Microb Ecol 49: 207-222

Landry MR, Hassett RP (1982) Estimating the grazing impact of marine micro-zooplankton. Mar Biol 67: 283-288

> Landry MR, Kirshtein J, Constantinou J (1995) A refined dilution technique for measuring the community grazing impact of microzooplankton, with experimental tests in the central equatorial Pacific. Mar Ecol Prog Ser 120: 53-63

> Landry MR, Selph KE, Yang EJ (2011) Decoupled phytoplankton growth and microzooplankton grazing in the deep euphotic zone of the eastern equatorial Pacific. Mar Ecol Prog Ser 421:13-24

$>$ Lehrter JC, Pennock JR, McManus GB (1999) Microzooplankton grazing and nitrogen excretion across a surface estuarine-coastal interface. Estuaries 22:113-125

> Long A, McDaniel LD, Mobberley J, Paul JH (2008) Comparison of lysogeny (prophage induction) in heterotrophic bacterial and Synechococcus populations in the Gulf of Mexico and Mississippi river plume. ISME J 2: 132-144

Longnecker K, Wilson MJ, Sherr EB, Sherr BF (2010) Effect of top-down control on cell-specific activity and diversity of active marine bacterioplankton. Aquat Microb Ecol 58: 153-165

> McManus GB, Griffin PM, Pennock JR (2004) Bacterioplankton abundance and growth in a river-dominated estuary: relationships with temperature and resources. Aquat Microb Ecol 37:23-32

Miki T, Jacquet S (2008) Complex interactions in the microbial world: underexplored key links between viruses, bacteria and protozoan grazers in aquatic environments. Aquat Microb Ecol 51:195-208

Miki T, Yamamura N (2005) Intraguild predation reduces bacterial species richness and loosens the viral loop in aquatic systems: 'kill the killer of the winner' hypothesis. Aquat Microb Ecol 40:1-12

Murrell MC, Lores EM (2004) Phytoplankton and zooplankton seasonal dynamics in a subtropical estuary: importance of cyanobacteria. J Plankton Res 26:371-382

- Nagano N, Decamp O (2004) Ingestion of a ciliated protozoa by first-feeding larval stage of Pacific white shrimp, Litopenaeus vannamei (Boone). Aquacult Res 35: 516-518

Ortmann AC, Suttle CA (2009) Determination of virus abundance by epifluorescence microscopy. Methods Mol Biol 501:87-95

> Ory P, Hartmann HJ, Jude F, Dupuy C and others (2010) Pelagic food web patterns: do they modulate virus and nanoflagellate effects on picoplankton during the phytoplankton spring bloom? Environ Microbiol 12: 2755-2772

Palomares-García R, Bustillos-Guzmán JJ, López-Cortés D (2006) Pigment-specific rates of phytoplankton growth and microzooplankton grazing in a subtropical lagoon. J Plankton Res 28:1217-1232

Park K, Kim CK, Schroeder WW (2007) Temporal variability in summertime bottom hypoxia in shallow areas of Mobile Bay, Alabama. Estuaries Coasts 30:54-65

$>$ Paterson HL, Knott B, Koslow AJ, Waite AM (2008) The grazing impact of microzooplankton off south west West- ern Australia: as measured by the dilution technique. J Plankton Res 30:379-392

Pedrós-Alió C, Calderón-Paz JI, Gasol JM (2000) Comparative analysis shows that bacterivory, not viral lysis, controls the abundance of heterotrophic prokaryotic plankton. FEMS Microbiol Ecol 32:157-165

Pepin P, Dower JF (2007) Variability in the trophic position of larval fish in a coastal pelagic ecosystem based on stable isotope analysis. J Plankton Res 29:727-737

$>$ Pernthaler J (2005) Predation on prokaryotes in the water column and its ecological implications. Nat Rev Microbiol 3:537-546

> Personnic S, Domaizon I, Sime-Ngando $\mathrm{T}$, Jacquet $\mathrm{S}$ (2009) Seasonal variations of microbial abundances and virus- versus flagellate-induced mortality of picoplancton in three peri-alpine lakes. J Plankton Res 31:1161-1177

$>$ Porter KG, Feig YS (1980) The use of DAPI for identifying and counting aquatic microflora. Limnol Oceanogr 25: 943-948

Putland JN, Iverson RL (2007) Microzooplankton: major herbivores in an estuarine planktonic food web. Mar Ecol Prog Ser 345:63-73

Rollwagen Bollens GC, Penry DL (2003) Feeding dynamics of Acartia spp. copepods in a large, temperate estuary (San Francisco Bay, CA). Mar Ecol Prog Ser 257:139-158

Schroeder WW, Wiseman WJ Jr (1999) Geology and hydrodynamics of Gulf of Mexico estuaries. In: Bianchi TS, Pennock JR, Twilley RR (eds) Biogeochemistry of Gulf of Mexico estuaries. John Wiley, New York, NY, p 3-28

Strom SL, Welschmeyer NA (1991) Pigment-specific rates of phytoplankton growth and microzooplankton grazing in the open subarctic Pacific Ocean. Limnol Oceanogr 36: $50-63$

> Suttle CA (2007) Marine viruses - major players in the global ecosystem. Nat Rev Microbiol 5:801-812

> Suttle CA, Chan AM (1993) Marine cyanophages infecting oceanic and coastal strains of Synechococcus: abundance, morphology, cross-infectivity and growth characteristics. Mar Ecol Prog Ser 92:99-109

> Suttle CA, Chan AM (1994) Dynamics and distribution of cyanophages and their effect on marine Synechococcus spp. Appl Environ Microbiol 60:3167-3174

Szedlmayer ST, Conti J (1999) Nursery habitats, growth rates, and seasonality of age-0 red snapper, Lutjanus campechanus, in the northeast Gulf of Mexico. Fish Bull 97:626-635

> Thomas R, Berdjeb L, Sime-Ngando T, Jacquet S (2011) Viral abundance, production, decay rates and life strategies (lysogeny versus lysis) in Lake Bourget (France). Environ Microbiol 13:616-630

Tijdens M, Van De Waal DB, Slovackova H, Hoogveld HL, Gons HJ (2008) Estimates of bacterial and phytoplankton mortality caused by viral lysis and microzooplankton grazing in a shallow eutrophic lake. Freshw Biol 53: 1126-1141

Van Heukelem L, Thomas CS (2001) Computer-assisted high-performance liquid chromatography method development with applications to the isolation and analysis of phytoplankton pigments. J Chromatogr A 910:31-49

- Waterhouse TY, Welschmeyer NA (1995) Taxon-specific analysis of microzooplankton grazing rates and phytoplankton growth rates. Limnol Oceanogr 40:827-834

Weinbauer MG (2004) Ecology of prokaryotic viruses. FEMS Microbiol Rev 28:127-181 
Weinbauer MG, Hornák K, Jezbera J, Nedoma J, Dolan JR, Šimek K (2007) Synergistic and antagonistic effects of viral lysis and protistan grazing on bacterial biomass, production and diversity. Environ Microbiol 9:777-788

Wen K, Ortmann AC, Suttle CA (2004) Accurate estimation of viral abundance by epifluorescence microscopy. Appl Environ Microbiol 70:3862-3867

Whitledge TE, Malloy SC, Patron CJ, Wirick CO (1981) Automated nutrient analysis in seawater. 51398: 216, National Laboratory. Brookhaven National Lab, Brookhaven, NY

Wilhelm SW, Suttle CA (1999) Viruses and nutrient cycles in the sea-viruses play critical roles in the structure and function of aquatic food webs. BioScience 49:781-788

Wilhelm SW, Brigden SM, Suttle CA (2002) A dilution technique for the direct measurement of viral production: a

Editorial responsibility: Hugh Ducklow, Woods Hole, Massachusetts, USA comparison in stratified and tidally mixed coastal waters. Microb Ecol 43:168-173

- Williams CJ, Lavrentyev PJ, Jochem FJ (2008) Bottom-up and top-down control of heterotrophic bacterioplankton growth in a phosphorus-depleted subtropical estuary, Florida Bay, USA. Mar Ecol Prog Ser 372:7-18

> York JK, Costas BA, McManus GB (2010) Microzooplankton grazing in green water-results from two contrasting estuaries. Estuaries Coasts 34:373-385

Zar J (1999) Biostatistical analysis, 4th edn. Prentice-Hall, London

Zhang R, Weinstock GM, Qian PY (2007) Viruses and flagellates sustain apparent richness and reduce biomass accumulation of bacterioplankton in coastal marine waters. Environ Microbiol 9:3008-3018

Submitted: April 6, 2011; Accepted: October 15, 2011

Proofs received from author(s): November 28, 2011 